\title{
Assessing the risk of venous thromboembolic events in women taking progestin-only contraception: a meta-analysis
}

\author{
(c) (1) (8) OPEN ACCESS
}

\author{
S Mantha senior staff haematologist ${ }^{1}, \mathrm{R}$ Karp clinical fellow in medicine ${ }^{2}$, V Raghavan clinical fellow \\ in medicine ${ }^{3}$, N Terrin associate professor of medicine ${ }^{4}, \mathrm{~K}$ A Bauer professor of medicine ${ }^{25}, \mathrm{~J} \mathrm{I}$ \\ Zwicker assistant professor of medicine ${ }^{2}$
}

${ }^{1}$ Division of Hematology-Oncology, Lahey Clinic, Burlington, MA, USA; ${ }^{2}$ Beth Israel Deaconess Medical Center, Harvard Medical School, Divisions of Thrombosis and Hemostasis and Hematology-Oncology, 330 Brookline Ave, Boston, MA 02215, USA; ${ }^{3}$ Harvard Medical School, Mt Auburn Hospital, Cambridge, MA; ${ }^{4}$ Institute for Clinical Research and Health Policy Studies, Tufts Medical Center, Boston, MA; ${ }^{5} \mathrm{Harvard}$ Medical School, VA Boston Healthcare System, Boston, MA

\begin{abstract}
Objectives To evaluate the risk of venous thromboembolic events associated with the use of progestin-only contraception and whether that risk differs with the mode of drug delivery (oral, intrauterine, or depot injection).

Design Systematic review and meta-analysis of randomised controlled trials and observational studies.

Data sources Pubmed, Embase, Cochrane Library, and reference lists of relevant reviews.

Study selection Randomised controlled trials and case-control, cohort, and cross sectional studies with venous thromboembolic outcome for progestin-only contraception reported relative to a non-hormone comparator group.

Data extraction Data were extracted by two independent investigators, and consensus for inclusion was reached after assessment by additional investigators.

Results Among the 2022 unique references identified by all searches, eight observational studies fulfilled inclusion criteria. A total of 147 women across all studies were diagnosed with a venous thromboembolic event while taking progestin-only contraception, and the summary measure for the adjusted relative risk of a venous thromboembolic episode for users versus non-users of a progestin-only contraceptive was, based on the random effects model, $1.03(95 \% \mathrm{Cl} 0.76$ to 1.39). Subgroup analysis confirmed there was no association between venous thromboembolic risk and progestin-only pills (relative risk 0.90 (0.57 to $1.45)$ ) or a progestin intrauterine device $(0.61$ (0.24 to 1.53$)$ ). The relative risk of a venous thromboembolic event for users of an injectable progestin versus non-users was 2.67 (1.29 to 5.53 ).
\end{abstract}

Conclusions Published data assessing the risk of venous thromboembolism in women prescribed progestin-only contraception are limited. In this meta-analysis of eight observational studies, the use of progestin-only contraception was not associated with an increased risk of venous thromboembolism compared with non-users of hormonal contraception. The potential association between injectable progestins and thrombosis requires further study.

\section{Introduction}

Since their introduction in the 1960s, combined oestrogen-progestin oral contraceptives have been associated with an increased risk of venous thromboembolic events. This thrombotic risk was attributed to the oestrogen content, which prompted the development of oral contraceptives containing less oestrogen. Use of formulations containing lower dose oestrogen still confer about twofold to fourfold increased risk of venous thromboembolic events compared with non-use. ${ }^{1-5}$ Epidemiological data suggest that subsequent changes in the composition of combined oral contraceptives by altering the progestin content can exacerbate thrombotic risk. Accordingly, newer progestins such as desogestrel, gestodene, and norgestimate have been associated with a greater venous thromboembolic risk than the older progestins such as levonorgestrel, lynestrenol, and norethisterone. ${ }^{4-8}$ When combined with an oestrogen, the newer progestins increase activated protein $\mathrm{C}$ resistance more than older progestins, which may account for the observed increased incidence of venous thromboembolism. ${ }^{9-12}$ Despite evidence that progestins may influence the risk of venous thromboembolism, there are only limited data evaluating the association between progestin-only 
contraception and thrombosis. Progestin-only contraception is generally thought to pose little risk of thrombosis and is recommended for women at high risk-such as post partum or with hereditary thrombophilia or a history of venous thromboembolism. ${ }^{13}{ }^{14}$ We performed a meta-analysis to evaluate the risk of venous thromboembolism associated with progestin-only contraception.

\section{Methods}

We performed a systematic review and meta-analysis of studies to evaluate the hypothesis that progestin-only contraceptives do not increase the risk of venous thromboembolic events. We conducted a literature search of journal articles published on or before 31 December 2011 using PubMed, Embase, and the Cochrane Database of Systematic Reviews. The index (MeSH or Emtree) fields were queried for the key words "progestin," "progesterone," "progestogen," "progestagen," "gestagen," "contraceptive," "thrombosis," "thromboembolism," and "thrombotic" (see appendix on bmj.com). Because of available resources, we considered only English language publications. We also performed a hand search of all the references included in a previous meta-analysis that analysed progesterone-only contraception and the risk of venous thromboembolic events ${ }^{15}$ and a review of contraception in thrombophilic adolescents. ${ }^{16}$

\section{Inclusion criteria}

Studies were included if they met all of the following conditions: a randomised trial or case-control, cohort, or cross sectional study (prospective or retrospective); presence of a treatment arm featuring use of progestin-only contraceptives and a control arm with no hormone use; use of progestin for the purpose of contraception only (excluding postcoital contraception); independent analysis of premenopausal women; incidence of venous thromboembolic events (defined as deep venous thrombosis or pulmonary embolism) reported; study featured human data only; one or more of three possible administration routes (oral, injectable, or intrauterine) were considered.

\section{Data extraction}

The initial search of the three databases was performed by SM; the references obtained were screened independently by two reviewers (RK and VR). Abstracts were assessed for relevance, and the full text of potentially suitable articles were retrieved. Each of those papers was assessed independently by the two reviewers (RK and VR) for inclusion in the meta-analysis; the reason for exclusion was noted for rejected articles. Two other reviewers (SM and JIZ) read the final subset of papers retained; mutual consensus was required for a study to be included in the analysis.

\section{Validity assessment}

Two reviewers (SM and JIZ) independently qualitatively evaluated the risk of confounding and the design quality of selected studies. Observational studies were assessed as suggested by the Meta-analysis of Observational Studies in Epidemiology (MOOSE) Group. ${ }^{17}$ The characteristics of individuals in the case and control groups or exposed and unexposed patients were compared; the use of matching or stratification was noted, and covariates used for adjustment in multivariate analysis were recorded. For randomised trials, the plan was to use the Cochrane Collaboration's tool for assessing risk of bias. ${ }^{18}$

\section{Statistical analysis}

We estimated the risk ratio of venous thromboembolism for users of progestin-only oral contraceptives versus non-users. Venous thromboembolism was defined as including both deep venous thrombosis and pulmonary embolism. We assumed that venous thromboembolic events had a low incidence $(<10 \%$ a year) in women aged $<50$ years taking oral contraceptives; this was based on previous reports estimating the yearly incidence of those events to about $0.06 \%$ per year. ${ }^{4}$ For infrequent events, the risk ratio, odds ratio, and rate ratio are considered equivalent measures of relative risk. ${ }^{19}$ With this in mind, we used the Comprehensive Meta-Analysis (CMA) version 2.2 software platform, entering each measure of relative risk in the same data table as if it were a risk ratio. The DerSimonian and Laird random effects model was used with the study as the unit of analysis. The primary analysis was performed with the adjusted measures of effect.

As a secondary analysis, we estimated the adjusted risk ratio of venous thromboembolism for users versus non-users of a hormone in each subgroup according to route of administration (oral, injectable and intrauterine). Additionally, an unadjusted odds ratio of venous thromboembolic event for users versus non-users of progestin was calculated using the raw event data. Heterogeneity across studies was estimated by means of the $\mathrm{I}^{2}$ statistic, itself calculated from the Q statistic. Sensitivity analysis was performed by repeating the primary analysis while excluding selected subgroups in order to determine if they had an inordinate effect on the estimated measure of effect.

\section{Results}

A total of 2045 references were identified: 1827 from PubMed, 215 from Embase, and none from the Cochrane Database of Systematic Reviews (fig $1 \Downarrow$ ). Two journal articles were identified from reading reviews of the subject matter, ${ }^{15} 162021$ and one from personal knowledge of an author. ${ }^{22}$ After removal of duplicates, 2022 records remained and were screened for inclusion in the analysis. Of these, 1922 were excluded after review of the abstract for lack of pertinence, leaving 100 articles to be retrieved. The full text of these papers were evaluated: 92 were excluded, with eight remaining for analysis..$^{22-28}$ The reasons for exclusion were not being a case-control or cohort study or randomised trial $(n=41)$, results not reported separately for a progestin-only arm $(n=39)$, absence of a no hormone arm $(n=4)$, progestin not administered for contraception only $(n=4)$, results for venous thromboembolism not reported $(n=3)$, and old version of a study with a recent update $(n=1)$.

\section{Characteristics of included studies}

The methods used by the authors of the eight selected studies are summarised in table $1 \Downarrow$. Our search found no randomised trial including a group of women taking a progestin-only contraceptive versus a group taking no hormone; three studies were retrospective cohort analyses, and five were case-control studies. All the case-control studies matched participants by age, and all but one study evaluated patients taking a progesterone-only pill with some also including individuals with a depot or intrauterine progestin-only contraceptive. Only two studies made use of stratification, but all of them performed multivariate analysis. The regression techniques varied widely: logistic regression was the most common approach, ${ }^{20} 26-28$ followed by Poisson regression ${ }^{23} 24$ and Cox modelling. ${ }^{22}{ }^{23}$ Body mass index was the variable most commonly adjusted for, with five sets of authors using it in their model. Two of the three retrospective cohort studies adjusted results for age in 
multivariate analysis. After considering these details, our reviewers determined that all of the eight papers retrieved in the search were of sufficient quality to be included in the meta-analysis.

A total of 147 women sustained a venous thromboembolic event, and table $2 \Downarrow$ shows the results of the articles retained for final analysis. The largest study was that of Lidegaard et al, ${ }^{24}$ with 1882 episodes of venous thromboembolism recorded in the combined group of individuals exposed to a progestin or to no hormone, followed by the WHO study, ${ }^{27}$ which featured 667 cases of venous thromboembolism for progestin-only users and non-users. The remaining six papers included a total of 777 events. The mean ages of case and control groups or exposed and unexposed groups were similar in the articles where the data were available. Since logistic regression was used in most papers, the odds ratio was the most common measure of effect.

\section{Risk of venous thromboembolism}

The adjusted relative risk of a venous thromboembolic event for users of progestin-only contraception versus non-users varied from 0.68 to 1.93 , as shown in table $3 \Downarrow$. None of the studies reported a statistically significant difference in the risk of venous thromboembolic event for users versus non-users of progestin-only contraceptive, whether for subgroups of users or all users versus non-users. However, Lidegaard et al reported the results for three different progestin-only formulations separately. ${ }^{24}$ We combined these three risk ratio estimates, corresponding to the three progestins, using the random effect models and setting the study as the unit of analysis. We assumed the three estimates were independent because there was insufficient information to account for their dependence. Hence the confidence interval of the estimate ( 0.61 to 0.98$)$ may be too narrow (table $2 \Downarrow$ ).

The summary measure for the adjusted relative risk of a venous thromboembolic event for users versus non-users of a progestin-only contraceptive was 1.03 (95\% CI 0.76 to1.39) with the random effects model (fig $2 \Downarrow$ ). This value was similar to the one obtained by combining the crude results (relative risk 1.21 (0.92 to 1.59)). However, the largest study (by Lidegaard et $\mathrm{al}^{24}$ ) could not be included in this latter estimate because the numbers of exposed and unexposed individuals were not provided (fig $3 \Downarrow$ ).

Subset analysis was performed on the adjusted results with the random effects model. A total of 54 women developed a venous thromboembolic event while taking a progestin-only pill (excluding the study by Vasilakis et al, ${ }^{25}$ which did not specify the route of administration), and they showed no significant increase in risk of venous thromboembolism compared with non-users (relative risk 0.90 ( 0.57 to 1.45$))$. On the other hand, the relative risk of an event for users of an injectable progestin formulation versus non-users was 2.67((1.29 to 5.53) (fig $4 \Downarrow$ ). Only two studies could be used to compute this value because no other article reported the results separately for that subgroup. Those two papers featured a total of 31 venous thromboembolic events in users of injectable progestins, which represents $21 \%$ of all cases in progestin-only users among all of the eight studies. Similarly, only two papers reported the results for the risk of venous thromboembolism in users of a progestin-only intrauterine device, and the combined measure of effect was 0.61 ( 0.24 to 1.53 ). These two studies reported 58 thromboembolic events in users of a progestin-only intrauterine device, which corresponds to $39 \%$ of all such episodes in progestin-only users among all of the eight studies. Notably, most of the information on these thromboembolic events comes from Lidegaard et al, ${ }^{24}$ with 55 venous thromboembolic event episodes in comparison with only three episodes in the paper from van Hylckama Vlieg et al. ${ }^{26}$

Heterogeneity was low, with an $\mathrm{I}^{2}$ of $24 \%$ and $\mathrm{P}=0.24$ for the adjusted results (fig $2 \Downarrow$ ). Sensitivity analysis was done by repeating the meta-analysis with one of the studies removed on an iterative basis: for all iterations, the $95 \%$ confidence intervals overlapped largely with those of the main analysis (data not shown).

\section{Discussion}

The primary objective of this meta-analysis is to assess the risk of venous thromboembolic events in women taking progestin-only contraception compared with non-users. A total of eight studies were included in this analysis, and the summary statistic did not identify a significant risk of venous thromboembolism associated with use of progestin-only contraception. There was a low degree of heterogeneity between studies, and we performed subgroup analysis to determine whether the apparent lack of association with venous thromboembolism was independent of route of administration of progestin (oral, depot injection, or intrauterine device).

All studies except that of van Hylckama Vlieg et $\mathrm{al}^{26}$ included patients taking an oral progestin; pooling of the results for the five papers reporting results separately for that subgroup indicated no increase in risk of venous thromboembolism for users versus non-users. The oral formulations included in this meta-analysis consisted of numerous different compounds, so it is not possible to evaluate a relation between risk of venous thromboembolism and individual types of progestin. In the studies that included women using a progestin-only intrauterine device, no excess risk of venous thromboembolism was detected. However, our analysis suggests that depot administration more than doubles the risk of venous thromboembolism. Only two studies reported results separately for this subgroup, representing about a fifth of the total number of venous thromboembolic episodes in the progestin-only users for the eight studies.

The relative safety of progestin-only contraception by oral and intrauterine delivery may in part be explained by dose, absorption, or metabolism. The amount of progestin included in a progestin-only "mini-pill" is considerably less than that commonly supplied in a combined oestrogen-progestin oral contraceptive. For instance, norethindrone is the only marketed progestin-only pill marketed in the United States, and when used alone the dose is $0.35 \mathrm{mg}$ daily or about a third of the dose commonly found in combined oestrogen-progestin formulations. ${ }^{29}$ Similarly, the levonorgestrel-containing intrauterine device releases about $20 \mu \mathrm{g}$ of levonorgestrel daily, most of which is concentrated in the endometrium with plasma concentrations ranging between 74 and $166 \mathrm{pg} / \mathrm{mL} .{ }^{30}$ By comparison, after intramuscular injection of medroxyprogesterone $150 \mathrm{mg}$, the peak plasma concentration is $2500-7000 \mathrm{pg} / \mathrm{mL}$ and remains greater than $430 \mathrm{pg} / \mathrm{mL}$ at three months. ${ }^{31} 32$

Different progestins are also known to influence the risk of thrombosis differently. Evidence suggests that third generation progestins such as desogestrel in combination with oestrogen are more prothrombotic than earlier formulations such as levonorgestrel or norethisterone. ${ }^{4-8}{ }^{24}$ Progestins can modulate oestrogen induced activated protein $\mathrm{C}$ resistance ${ }^{12}$ and have been shown to influence the cellular expression of tissue factor ${ }^{33} 34$ as well as circulating tissue factor pathway inhibitor. ${ }^{10}{ }^{35}$ In a mouse model of vascular injury administration of medroxyprogesterone significantly shortened the time to 
development of an occlusive thrombus. ${ }^{36}$ In the studies included in this meta-analysis, the vast majority of women used older progestins, potentially masking an association with venous thromboembolism. However, the study by Lidegaard et al analysed more than 29000 women years for a third generation progestin-only pill and failed to show any increased risk associated with its use (adjusted venous thromboembolic event rate 0.64 (95\% confidence interval 0.29 to 1.42$)){ }^{24}$

\section{Strengths and limitations of the meta-analysis}

A potential limitation of this study remains the paucity of published literature on the topic, with a total of only eight studies available for analysis and no randomised trials. The inclusion of several recently published large epidemiological studies permits a more robust summary analysis with tighter confidence intervals than a previously published meta-analysis, which evaluated only four studies (without an analysis according to method of delivery). ${ }^{15}$ The consistency of the results for different oral formulations reassures the validity of the measure of effect for this group. The subgroup analysis for intrauterine devices and depot injections should be interpreted with caution because of the limited number of studies available for analysis.

Control for confounding in the individual studies was usually limited. Also, selection bias cannot be excluded as the basis of the significant association between depot administration and venous thromboembolism. However, this is unlikely as the study that contributed most to the summary statistic for depot injection specifically excluded highest risk women (that is, those with a personal history of venous thromboembolism) ${ }^{26} \mathrm{We}$ did not observe evidence of publication or reporting bias. However, the small number of studies limits our ability to formally assess these potential biases. ${ }^{37}$ Bias and lack of adjustment for confounders at the level of the individual studies cannot be corrected in the meta-analysis, so the validity of these results is dependent on quality of the primary observational data.

\section{Implications for patient care}

Deciding on the optimal contraceptive method is often difficult for women considered at increased risk of venous thromboembolism, such as those with a history of thrombophilia. The World Health Organization and US Centers for Disease Control and Prevention publish similarly titled guidelines on the topic, "Medical eligibility criteria for contraceptive use." All modes of progestin-only contraception are advocated, even for higher risk women such as those with hereditary thrombophilia, history of oestrogen induced venous thromboembolism, or history of recurrent venous thromboembolism. ${ }^{13} 14$ This meta-analysis offers further reassurance that such guidance is appropriate. However, only two of the studies were specifically conducted in high risk populations, with a total of 360 women. ${ }^{22} 23$ Our analysis also suggests that the relative safety of progestin-only agents may be limited to oral and intrauterine formulations, whereas the thrombotic risk associated with injectable progestin seems to be of similar magnitude to oral contraceptives containing oestrogen.

\section{Conclusion}

Collectively, progestin-only contraceptives were not associated with an increased risk of venous thromboembolism compared with non-users in a limited number of observational studies. In the subset of women in this analysis prescribed injectable progestins, there was an approximate twofold increase in thrombotic risk. These results require confirmation as selection bias cannot be excluded. In the interim, we suggest consideration of non-injectable forms of progestin-only contraception for highest risk women.

Contributors: RK and VR performed initial literature searches and data extraction. JIZ and SM performed data extraction, statistical analysis, and coauthored the manuscript. NT provided statistical analysis and editing. KAB performed manuscript review and editing.

Funding: This study was funded by the National Center for Research Resources and the National Center for Advancing Translational Sciences, National Institutes of Health (grant No UL1 RR025752). The content is solely the responsibility of the authors and does not necessarily represent the official views of the $\mathrm{NIH}$.

All authors have completed the ICMJE uniform disclosure form at www. icmje.org/coi_disclosure.pdf (available on request from the corresponding author) and declare: support from US National Institute of Health for the submitted work; no financial relationships with any organisations that might have an interest in the submitted work in the previous three years; no other relationships or activities that could appear to have influenced the submitted work.

Data sharing: No additional data available.

1 Helmerhorst FM, Bloemenkamp KW, Rosendaal FR, Vandenbroucke JP. Oral contraceptives and thrombotic disease: risk of venous thromboembolism. Thromb Haemost 1997;78:327-33.

2 Vessey M, Mant D, Smith A, Yeates D. Oral contraceptives and venous thromboembolism: findings in a large prospective study. BMJ 1986;292:526

3 Gerstman BB, Piper JM, Tomita DK, Ferguson WJ, Stadel BV, Lundin FE. Oral contraceptive estrogen dose and the risk of deep venous thromboembolic disease. Am $J$ Epidemiol 1991;133:32-7.

4 Lidegaard O, Lokkegaard E, Svendsen AL, Agger C. Hormonal contraception and risk of venous thromboembolism: national follow-up study. BMJ 2009;339:1-8.

5 Van Hylckama Vlieg A, Helmerhorst FM, Vandenbroucke JP, Doggen CJ, Rosendaal FR. The venous thrombotic risk of oral contraceptives, effects of oestrogen dose and progestogen type: results of the MEGA case-control study. BMJ 2009;339:b2921.

6 Jick H, Jick SS, Gurewich V, Myers MW, Vasilakis C. Risk of idiopathic cardiovascular death and nonfatal venous thromboembolism in women using oral contraceptives with differing progestagen components. Lancet 1995;346:1589-93.

7 World Health Organization Collaborative Study of Cardiovascular Disease and Steroid Hormone Contraception. Venous thromboembolic disease and combined oral contraceptives: results of international multicentre case-control study. Lancet 1995;346:1575-82.

8 Kemmeren JM, Algra A, Grobbee DE. Third generation oral contraceptives and risk of venous thrombosis: meta-analysis. BMJ 2001;323:131-4

9 Rosing J, Middeldorp S, Curvers J, Christella M, Thomassen LG, Nicolaes GA, et al. Low-dose oral contraceptives and acquired resistance to activated protein $C$ : a randomised cross-over study. Lancet 1999;354:2036-40.

10 Van Vliet HA, Bertina RM, Dahm AE, Rosendaal FR, Rosing J, Sandset PM, et al. Different effects of oral contraceptives containing different progestogens on protein $\mathrm{S}$ and tissue factor pathway inhibitor. J Thromb Haemost 2008;6:346-51.

11 Tchaikovski SN, van Vliet HA, Thomassen MC, Bertina RM, Rosendaal FR, Sandset PM, et al. Effect of oral contraceptives on thrombin generation measured via calibrated automated thrombography. J Thromb Haemost 2007;98:1350-6.

12 Kemmeren JM, Algra A, Meijers JC, Tans G, Bouma BN, Curvers J, et al. Effect of secondand third-generation oral contraceptives on the protein $C$ system in the absence or presence of the factor VLeiden mutation: a randomized trial. Blood 2004;103:927-33.

13 Centers for Disease Control and Prevention. US medical eligibility criteria for contraceptive use. MMWR Early Release 2010;59:1-86.

14 Department of Reproductive Health WHO. Medical eligibility criteria for contraceptive use . 4th ed. WHO Press, 2009

15 Bergendal A, Odlind V, Persson I, Kieler H. Limited knowledge on progestogen-only contraception and risk of venous thromboembolism. Acta Obstet Gynecol Scand 2009;88:261-6.

16 Rott $\mathrm{H}$. Hormonal contraception in thrombophilic adolescents. Risk of thrombosis and recommendations. Hamostaseologie 2012;32:15-21.

17 Stroup DF, Berlin JA, Morton SC, Olkin I, Williamson GD, Rennie D, et al for the Meta-analysis Of Observational Studies in Epidemiology (MOOSE) Group. Meta-analysis of observational studies in epidemiology: a proposal for reporting. JAMA 2000;283:2008-12.

18 Higgins JPT, Green S, Cochrane Collaboration. Cochrane handbook for systematic reviews of interventions. Wiley-Blackwell, 2008.

19 Pagano M, Gauvreau K. Principles of biostatistics . 2nd ed. Duxbury, 2000

20 Heinemann LA, Assmann A, DoMinh T, Garbe E. Oral progestogen-only contraceptives and cardiovascular risk: results from the Transnational Study on Oral Contraceptives and the Health of Young Women. Eur J Contraception Reprod Health 1999;4:67-73.

21 Meirik O, Farley TM, Sivin I. Safety and efficacy of levonorgestrel implant, intrauterine device, and sterilization. Obstet Gynecol 2001;97:539-47.

22 Vaillant-Roussel H, Ouchchane L, Dauphin C, Philippe P, Ruivard M. Risk factors for recurrence of venous thromboembolism associated with the use of oral contraceptives. Contraception 2011:84:e23-30.

23 Conard J, Plu-Bureau G, Bahi N, Horellou MH, Pelissier C, Thalabard JC. Progestogen-only contraception in women at high risk of venous thromboembolism. Contraception 2004;70:437-41 


\section{What is already known on this topic}

The risk of venous thromboembolic events associated with use of hormone contraceptives is influenced by the dose of oestrogen and formulation of progestin

Progestin-only contraception is the preferred hormone contraceptive in women considered higher risk for development of venous thromboembolism

\section{What this study adds}

This meta-analysis of eight observational studies did not identify an association between oral progestin-only contraception and risk of venous thromboembolism

Subgroup analysis suggests that injectable progestin contraception is associated with an approximate twofold increased risk of risk of venous thromboembolism relative to women not taking hormonal contraception

24 Lidegaard O, Nielsen LH, Skovlund CW, Skjeldestad FE, Lokkegaard E. Risk of venous thromboembolism from use of oral contraceptives containing different progestogens and oestrogen doses: Danish cohort study, 2001-9. BMJ 2011;343:d6423.

25 Vasilakis $\mathrm{C}$, Jick $\mathrm{H}$, del Mar Melero-Montes M. Risk of idiopathic venous thromboembolism in users of progestagens alone. Lancet 1999;354:1610-1.

26 Van Hylckama Vlieg A, Helmerhorst FM, Rosendaal FR. The risk of deep venous thrombosis associated with injectable depot-medroxyprogesterone acetate contraceptives or a levonorgestrel intrauterine device. Arterioscler Thromb Vasc Biol 2010;30:2297-300.

27 World Health Organization Collaborative Study of Cardiovascular Disease and Steroid Hormone Contraception. Cardiovascular disease and use of oral and injectable progestogen-only contraceptives and combined injectable contraceptives. Results of an international, multicenter, case-control study. Contraception 1998;57:315-24.

28 Barsoum MK, Heit JA, Ashrani AA, Leibson CL, Petterson TM, Bailey KR. Is progestin an independent risk factor for incident venous thromboembolism? A population-based case-control study. Thromb Res 2010;126:373-8.

29 Stanczyk FZ, Mroszczak EJ, Ling T, Runkel R, Henzl M, Miyakawa I, et al. Plasma levels and pharmacokinetics of norethindrone and ethinylestradiol administered in solution and as tablets to women. Contraception 1983;28:241-51.

30 Nilsson CG, Lahteenmaki PL, Luukkainen T, Robertson DN. Sustained intrauterine release of levonorgestrel over five years. Fertil Steril 1986;45:805-7.

31 Nanda K, Amaral E, Hays M, Viscola MA, Mehta N, Bahamondes L. Pharmacokinetic interactions between depot medroxyprogesterone acetate and combination antiretroviral therapy. Fertil Steril 2008;90:965-71.

32 Bogdanov VY, Balasubramanian V, Hathcock J, Vele O, Lieb M, Nemerson Y. Alternatively spliced human tissue factor: a circulating, soluble, thrombogenic protein. Nat Med 2003;9:458-62.
33 Lockwood CJ, Murk W, Kayisli UA, Buchwalder LF, Huang ST, Funai EF, et al. Progestin and thrombin regulate tissue factor expression in human term decidual cells. $J$ Clin Endocrinol Metab 2009;94:2164-70.

34 Kato S, Pinto M, Carvajal A, Espinoza N, Monso C, Sadarangani A, et al. Progesterone increases tissue factor gene expression, procoagulant activity, and invasion in the breast cancer cell line ZR-75-1. J Clin Endocrinol Metab 2005;90:1181-8.

35 Shirk RA, Zhang Z, Winneker RC. Differential effects of estrogens and progestins on the anticoagulant tissue factor pathway inhibitor in the rat. J Steroid Biochem Molecular Biol 2005;94:361-8.

36 Freudenberger T, Oppermann M, Marzoll A, Heim HK, Mayer P, Kojda G, et al. Differential effects of medroxyprogesterone acetate on thrombosis and atherosclerosis in mice. $\mathrm{Br} J$ Pharmacol 2009;158:1951-60.

37 Sterne JA, Sutton AJ, loannidis JP, Terrin N, Jones DR, Lau J, et al. Recommendations for examining and interpreting funnel plot asymmetry in meta-analyses of randomised controlled trials. BMJ 2011;343:d4002.

\section{Accepted: 28 June 2012}

\section{Cite this as: BMJ 2012;345:e4944}

This is an open-access article distributed under the terms of the Creative Commons Attribution Non-commercial License, which permits use, distribution, and reproduction in any medium, provided the original work is properly cited, the use is non commercial and is otherwise in compliance with the license. See: http://creativecommons.org/licenses/bync/2.0/ and http://creativecommons.org/licenses/by-nc/2.0/legalcode. 


\section{Tables}

\begin{tabular}{|c|c|c|c|c|c|c|}
\hline Study & Inclusion criteria & Baseline risk ${ }^{*}$ & Format & Matching & Stratification† & $\begin{array}{l}\text { Adjustment factors in } \\
\text { multivariate analysis }\end{array}$ \\
\hline Barsoum et al, $2010^{28}$ & $\begin{array}{l}\text { Cases: diagnosis of deep vein } \\
\text { thrombosis or pulmonary embolism }\end{array}$ & Average & Case-control & $\begin{array}{l}\text { Age and } \\
\text { medical record } \\
\text { number }\end{array}$ & No & $\begin{array}{l}\text { BMI, recent hospitalisation, } \\
\text { recent surgery, nursing home } \\
\text { confinement, trauma or fracture, } \\
\text { active cancer, leg paresis, } \\
\text { varicose veins }\end{array}$ \\
\hline Conard et al, $2004^{23}$ & $\begin{array}{l}\text { Personal history of VTE with } \\
\text { presence of thrombophilia or family } \\
\text { history of VTE }\end{array}$ & High & $\begin{array}{l}\text { Retrospective } \\
\text { cohort }\end{array}$ & No & No & BMI, age, thrombophilia \\
\hline $\begin{array}{l}\text { Heinemann et al, } \\
1999^{20}\end{array}$ & $\begin{array}{l}\text { Cases: diagnosis of myocardial, } \\
\text { thromboembolic cerebrovascular } \\
\text { accident or VTE }\end{array}$ & Average & Case control & Age & No & $\begin{array}{l}\text { BMI, hypertension, smoking, } \\
\text { diabetes, alcohol consumption, } \\
\text { education }\end{array}$ \\
\hline $\begin{array}{l}\text { Lidegaard et al, } \\
2011^{24}\end{array}$ & $\begin{array}{l}\text { All Danish women aged 15-49 } \\
\text { years in 1995-2009 }\end{array}$ & Average & $\begin{array}{l}\text { Retrospective } \\
\text { cohort }\end{array}$ & No & $\begin{array}{l}\text { Certainty of } \\
\text { diagnosis }\end{array}$ & $\begin{array}{l}\text { Age, calendar year, level of } \\
\text { education }\end{array}$ \\
\hline $\begin{array}{l}\text { Vaillant-Roussel et } \\
\text { al, } 2011^{22}\end{array}$ & $\begin{array}{c}\text { One episode of VTE during use of } \\
\text { combined oral contraceptive or }<1 \\
\text { month after stopping }\end{array}$ & High & $\begin{array}{l}\text { Retrospective } \\
\text { cohort }\end{array}$ & No & No & Duration of exposure \\
\hline Vasilakis et al, $1999^{25}$ & $\begin{array}{l}\text { Cases and controls: to have } \\
\text { received } \geq 1 \text { prescription for a } \\
\text { progestin alone. Cases: idiopathic } \\
\text { VTE }\end{array}$ & Average & Case-control & $\begin{array}{l}\text { Age and } \\
\text { general } \\
\text { practice }\end{array}$ & No & BMI, smoking \\
\hline $\begin{array}{l}\text { Van Hylckama Vlieg } \\
\text { et al, } 2010^{26}\end{array}$ & Cases: first episode of VTE & Average & Case-control & Age & No & Age \\
\hline WHO, $1998^{27}$ & $\begin{array}{l}\text { Cases: VTE, stroke, or acute } \\
\text { myocardial infarction }\end{array}$ & Average & Case-control & Age & $\begin{array}{c}\text { Europe } v \\
\text { developing } \\
\text { countries, history } \\
\text { of hypertension, } \\
\text { smoking status }\end{array}$ & $\begin{array}{l}\text { BMI, number of live births, } \\
\text { hypertension, rheumatic heart } \\
\text { disease, family history of } \\
\text { premature heart attack }\end{array}$ \\
\hline
\end{tabular}

VTE=venous thromboembolic event. BMI=body mass index.

*Subjective assessment based on inclusion criteria.

tWithin the group of cancer-free women receiving a progestin-only agent. 


\begin{tabular}{|c|c|c|c|c|c|c|c|}
\hline \multirow[b]{2}{*}{ Study } & \multicolumn{2}{|c|}{ No of patients } & \multicolumn{3}{|c|}{ Progestin used } & \multicolumn{2}{|c|}{ Duration of exposure } \\
\hline & With a VTE* & $\begin{array}{l}\text { Without } \\
\text { VTE }^{\star}\end{array}$ & Route & Drug & Dose & $\begin{array}{l}\text { Cases or } \\
\text { exposed }^{*}\end{array}$ & $\begin{array}{l}\text { Controls or } \\
\text { unexposed }\end{array}$ \\
\hline \multirow[t]{2}{*}{$\begin{array}{l}\text { Barsoum et al, } \\
2010^{28}\end{array}$} & 1 & 1 & Oral & $\begin{array}{c}\text { Medroxyprogesterone } \\
\text { acetate } \dagger\end{array}$ & 5 or $10 \mathrm{mg} / \mathrm{day}$ & \multirow{2}{*}{\multicolumn{2}{|c|}{$N / A$}} \\
\hline & 2 & 1 & Inject & $\begin{array}{c}\text { Medroxyprogesterone } \\
\text { acetate } \dagger\end{array}$ & 150 or $400 \mathrm{mg}$ & & \\
\hline $\begin{array}{l}\text { Conard et al, } \\
2004^{23}\end{array}$ & 3 & 99 & Oral & Chlormadinone acetate & $\begin{array}{c}10 \text { mg daily, } 18-20 \\
\text { days/cycle }\end{array}$ & $\begin{array}{c}\text { Mean } 31.2(\mathrm{SD} \\
19.7) \text { months }\end{array}$ & $\begin{array}{l}\text { Mean } 35.0(\mathrm{SD} \\
17.7) \text { months }\end{array}$ \\
\hline $\begin{array}{l}\text { Heinemann et al, } \\
1999^{20}\end{array}$ & 7 & 54 & Oral & $\mathrm{N} / \mathrm{A}$ & & & \\
\hline \multirow{3}{*}{$\begin{array}{l}\text { Lidegaard et al, } \\
2011^{24}\end{array}$} & 9 & \multirow[t]{3}{*}{$N / A$} & Oral & Norethisterone & \multirow[t]{3}{*}{$N / A$} & \multicolumn{2}{|c|}{44168 women years } \\
\hline & 6 & & & Desogestrel & & \multicolumn{2}{|c|}{29187 women years } \\
\hline & 55 & & IUD & Levonorgestrel & & \multicolumn{2}{|c|}{155149 women years } \\
\hline $\begin{array}{l}\text { Vaillant-Roussel } \\
\text { et al, } 2011^{22}\end{array}$ & 7 & 27 & Oral & N/A & & Median 74 (ran & 3-434) months \\
\hline \multirow{2}{*}{$\begin{array}{l}\text { Vasilakis et al, } \\
1999^{25}\end{array}$} & \multirow[t]{2}{*}{2} & \multirow[t]{2}{*}{26} & Oral & \multirow[t]{2}{*}{$N / A$} & & \multirow{2}{*}{\multicolumn{2}{|c|}{$N / A$}} \\
\hline & & & Inject & & & & \\
\hline \multirow{2}{*}{$\begin{array}{l}\text { Van Hylckama } \\
\text { Vlieg et al, } \\
2010^{26}\end{array}$} & 20 & 15 & Inject & Medroxyprogesterone & $N / A$ & \multirow{2}{*}{\multicolumn{2}{|c|}{$N / A$}} \\
\hline & 3 & 26 & IUD & Levonorgestrel & & & \\
\hline \multirow[t]{7}{*}{ WHO, $1998^{27}$} & 21 & 63 & Oral & Levonorgestrel & $0.03 \mathrm{mg}$ & \multirow{7}{*}{\multicolumn{2}{|c|}{$\mathrm{N} / \mathrm{A}$}} \\
\hline & & & & Norgestrel & $0.075 \mathrm{mg}$ & & \\
\hline & & & & Ethynodiol diacetate & $0.5 \mathrm{mg}$ & & \\
\hline & & & & Lynestrenol & $0.5 \mathrm{mg}$ & & \\
\hline & & & & Norethisterone & $0.35 \mathrm{mg}$ & & \\
\hline & 11 & 34 & IUD & Medroxyprogesterone & $150 \mathrm{mg}$ & & \\
\hline & & & & Norethisterone oenanthate & $200 \mathrm{mg}$ & & \\
\hline
\end{tabular}

VTE=venous thromboembolic event. $\mathrm{N} / \mathrm{A}=$ data not available from the journal article. IUD=intrauterine device.

*Single value for combined group provided when breakdown not available.

†Women aged $\leq 45$ years received a progestin for contraception and other indications. 
Table 3| Total number of venous thromboembolic events and adjusted relative risk in women taking progestin-only contraceptives or no hormone among included studies

\begin{tabular}{|c|c|c|c|c|c|c|c|c|}
\hline \multirow[b]{3}{*}{ Study } & \multicolumn{2}{|c|}{ Mean (SD) age (years) } & \multicolumn{4}{|c|}{ No of patients } & \multirow{3}{*}{$\begin{array}{l}\text { Measure of } \\
\text { effect used }\end{array}$} & \multirow{3}{*}{$\begin{array}{c}\text { Adjusted } \\
\text { relative risk of } \\
\text { VTE for users } v \\
\text { non-users (95\% } \\
\text { Cl) }\end{array}$} \\
\hline & \multirow{2}{*}{$\begin{array}{l}\text { Cases (or } \\
\text { exposed) }\end{array}$} & \multirow{2}{*}{$\begin{array}{l}\text { Controls (or } \\
\text { unexposed) }\end{array}$} & \multicolumn{2}{|c|}{ Progestin } & \multicolumn{2}{|c|}{ No hormone } & & \\
\hline & & & VTE & No VTE & VTE & No VTE & & \\
\hline $\begin{array}{l}\text { Barsoum et al, } \\
2010^{28}\end{array}$ & $\mathrm{~N} / \mathrm{A}$ & $\mathrm{N} / \mathrm{A}$ & 3 & 2 & 98 & 133 & Odds ratio & $\begin{array}{c}1.20 \text { (0.40 to } \\
3.63)\end{array}$ \\
\hline $\begin{array}{l}\text { Conard et al, } \\
2004^{23}\end{array}$ & $29.6(8.6)$ & $29.7(8.7)$ & 3 & 99 & 6 & 96 & Rate ratio* & $0.80(0.2$ to 3.9$)$ \\
\hline $\begin{array}{l}\text { Heinemann et al, } \\
1999^{20}\end{array}$ & $34.5(6.6)$ & $34.0(7.4)$ & 7 & 54 & 174 & 1346 & Odds ratio & $\begin{array}{c}0.68(0.28 \text { to } \\
1.66)\end{array}$ \\
\hline $\begin{array}{l}\text { Lidegaard et al, } \\
2011^{24}\end{array}$ & $\mathrm{~N} / \mathrm{A}$ & $\mathrm{N} / \mathrm{A}$ & 70 & $\mathrm{~N} / \mathrm{A} \dagger$ & 1812 & N/A & Rate ratio§ & $\begin{array}{c}0.77(0.61 \text { to } \\
0.98) \rrbracket\end{array}$ \\
\hline $\begin{array}{l}\text { Vaillant-Roussel } \\
\text { et al, } 2011^{22}\end{array}$ & $\mathrm{~N} / \mathrm{A}$ & $\mathrm{N} / \mathrm{A}$ & 7 & 27 & 20 & 102 & Rate ratio** & $\begin{array}{c}1.30(0.50 \text { to } \\
3.00)\end{array}$ \\
\hline $\begin{array}{l}\text { Vasilakis et al, } \\
1999^{25}\end{array}$ & $\mathrm{~N} / \mathrm{A}$ & $\mathrm{N} / \mathrm{A}$ & 2 & 26 & 13 & 161 & $\mathrm{~N} / \mathrm{A}$ & 1.30 (0.3 to 6.8$)$ \\
\hline $\begin{array}{l}\text { Van Hylckama } \\
\text { Vlieg et al, } 2010^{26}\end{array}$ & $39.9(\mathrm{~N} / \mathrm{A})$ & $39.5(\mathrm{~N} / \mathrm{A})$ & 23 & 41 & 421 & 1102 & Odds ratio & $\begin{array}{c}1.38(0.65 \text { to } \\
2.90) \rrbracket\end{array}$ \\
\hline $\mathrm{WHO}, 1998^{27}$ & $\begin{array}{c}1.8(7.1) \text { for } \\
\text { oral, } 31.0(6.2) \\
\text { for injectable }\end{array}$ & $35.4(6.8)$ & 32 & 97 & 635 & 2288 & Odds ratio & $\begin{array}{c}1.93(0.97 \text { to } \\
3.84) 9\end{array}$ \\
\hline
\end{tabular}

VTE=venous thromboembolic event. N/A=information not reported in original paper.

*Obtained from Poisson regression (incidence rate ratio) and Cox proportional hazards regression (hazard ratio); result from the Cox model shown tIncidence rate/10000 woman years of VTE=2.0 to 3.5, depending on the type of progestin.

łIncidence rate/10000 woman years of VTE=3.7 for non-users.

§Obtained from Poisson regression (incidence rate ratio).

ISummary measure for all progestin-only contraceptive users versus non-users calculated based on the results from the different subgroups as reported in the original paper.

${ }^{\star *}$ Hazard ratio obtained from Cox proportional hazards regression. 


\section{Figures}

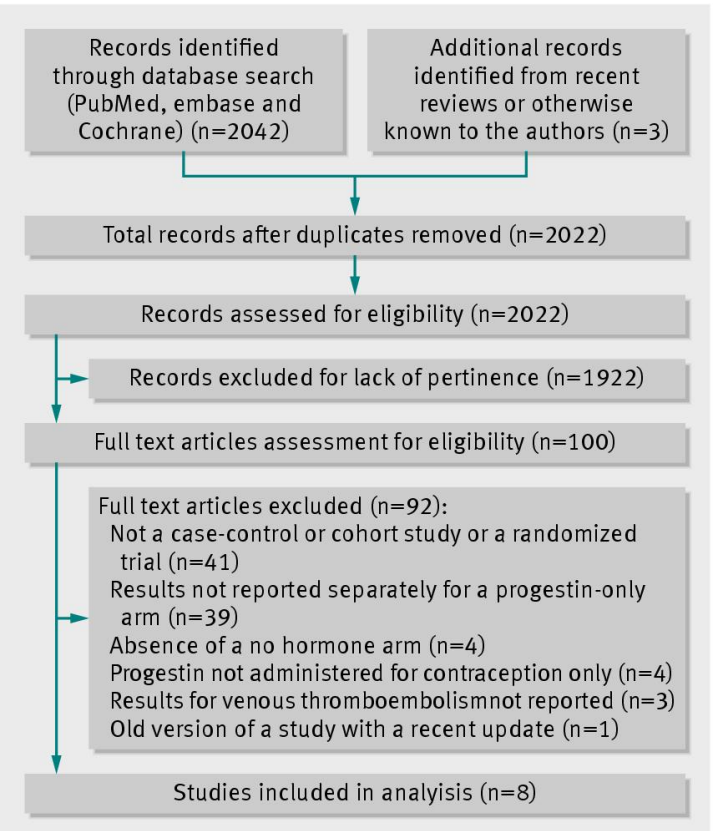

Fig 1 Flow diagram of studies included in meta-analysis

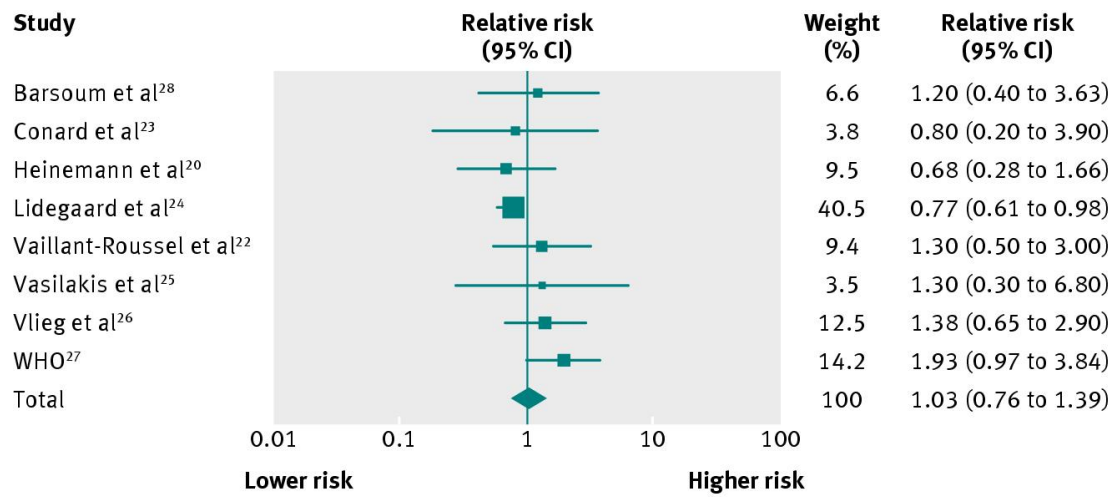

Test for heterogeneity: $Q=9.21, \mathrm{df}=7, \mathrm{I}^{2}=24 \%, \mathrm{P}=0.24$

Fig 2 Adjusted relative risk of venous thromboembolism for users versus non-users of a progestin-only contraceptive, all subgroups combined

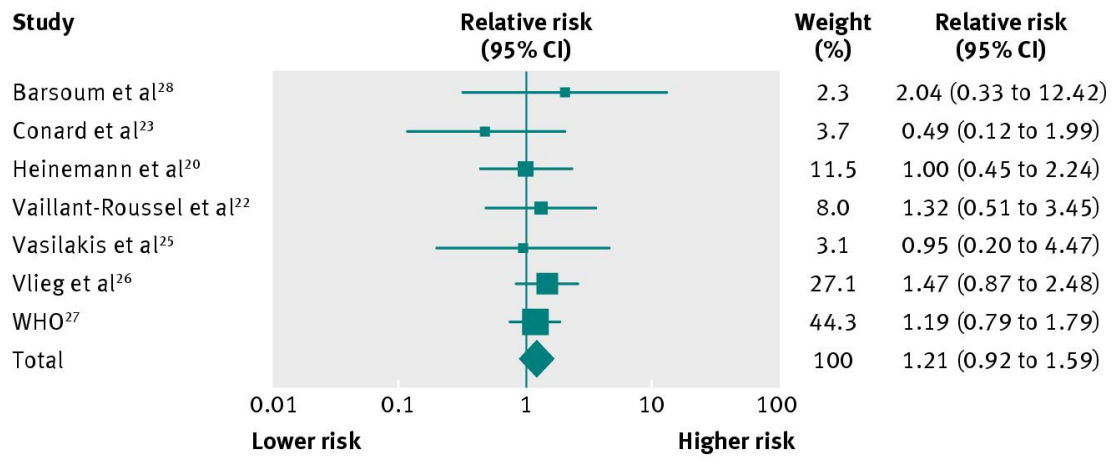

Test for heterogeneity: $Q=2.79, d f=6, l^{2}=0 \%, P=0.83$

Fig 3 Unadjusted relative risk of venous thromboembolism for users versus non-users of a progestin-only contraceptive, all subgroups combined 


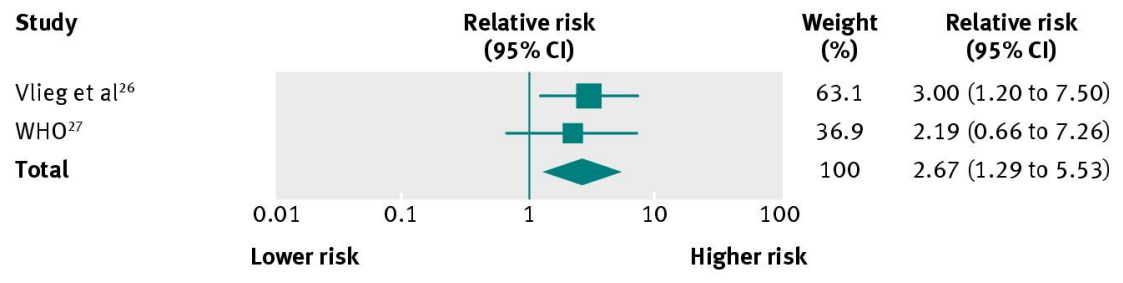

Test for heterogeneity: $Q=0.17, d f=1, l^{2}=0 \%, P=0.68$

Fig 4 Adjusted relative risk of venous thromboembolism for users versus non-users of a progestin-only contraceptive, injectable formulation only 